Vol. 5 (1996): 157-166.

\title{
Lysine supplementation of barley wet distillers' solids diets for growing-finishing pigs
}

Jarmo Valaja', Hilkka Siljander-Rasi and Timo Alaviuhkola

Agricultural Research Centre of Finland, Swine Research Station, Tervamäentie 179, FIN-05840 Hyvinkää, Finland

Asko Rantanen

Primalco Ltd., FIN-05200 Rajamäki, Finland

\begin{abstract}
A growth experiment was conducted to study the effect of different lysine supplementation levels of barley wet distillers' solids (WDS) diets on the performance and the carcass quality of pigs (25.5-95.5 kg live weight). A total of 160 pigs were divided into four groups of 40 animals. Four pigs of the same sex were placed in each pen and fed one of the four experimental diets: a barley-soyabean meal (SBM) control diet (167 g crude protein (CP) $/ \mathrm{kg}$ dry matter (DM) and $7.6 \mathrm{~g}$ lysine/feed unit (FU)) or three similar barley-WDS diets (204 g CP/kg DM) which were supplemented with synthetic lysine to contain $7.7,9.2$ or $10.7 \mathrm{~g}$ lysine/FU. Lysine supplementation linearly improved the daily weight gain (DG) and feed conversion ratio (FCR) of the pigs during growing $(1-5$ weeks $)(p<0.001)$, finishing (6th week onward) $(\mathrm{p}<0.001)$ and the whole experimental period $(\mathrm{p}<0.001)$. However, during the whole growing-finishing period the performance of the pigs levelled off at the lysine level of $9.2 \mathrm{~g} / \mathrm{FU}$ and daily supply of $18.0 \mathrm{~g}$, respectively (quadratic effect: $\mathrm{p}<0.05$ for DG and $\mathrm{p}<0.01$ for FCR). The pigs on the SBM diet grew faster and more efficiently than did the pigs on the WDS diets with similar lysine content $(\mathrm{p}<0.05)$.
\end{abstract}

Key words: swine, daily weight gain, feed conversion efficiency, amino acids, soyabean meal

${ }^{1}$ Current address: Agricultural Research Centre of Finland, Institute of Animal Production, FIN-31600 Jokioinen, Finland

\section{Introduction}

The amino acid composition of grain protein, and especially lysine content, is insufficient when compared to the requirements of growing pigs. Similarly, many industrial by-products, e.g. barley wet distillers' solids (WDS), originating from grain contain low amounts of lysine in their protein (Näsi and Aimonen 1992, Valaja et al. 1995).

In pigs, the protein utilisation of the diets composed solely of WDS is poor, because a large part of the protein is excreted via urine, where it increases environmental pollution (Valaja and Näsi 1996). However, the lysine supplementation of WDS diets has increased protein utilisa- 


\section{Valaja, J. et al.: Lysine supplementation of barley wet distillers' solids diets for growing-finishing pigs}

tion in pigs to the level of soyabean meal (SBM) (Valaja and Näsi 1996). Optimal amino acid balance is needed for the effective utilisation of dietary protein. Recommendations for dietary lysine supply derived from different sources can only be applied in situations similar to those in the experiments (Susenbeth 1995). No studies have been conducted to set the amino acid recommendations for the Finnish pigs of high genetic potential fed diets composed of WDS.

The performance of the pigs fed conventional distillers' feeds has been variable, mainly because of the high fibre content and the differences in the severity of the drying process (Alaviuhkola 1978, Suomi 1980, Newman and Gras 1983). In the growth experiment with WDS, the performance of the pigs has been only satisfactory (Valaja et al. 1995). However, the digestibility of amino acids and protein in WDS has been high in the former experiments (Näsi and Aimonen 1992, Valaja and Näsi 1996, Buraczewska et al. 1996). Because of the conflicting results in the performance and digestibility experiments, more information was needed on the suitability of wet distillers' solids for growing-finishing pigs and the optimal lysine supplementation of the diet.

The objectives of the present experiment were to determine the effects of increasing lysine supplementation in WDS diets on the performance and carcass quality of growing-finishing pigs and, to set an optimal lysine supply level for WDS. The performance responses of the pigs on the WDS diets were also compared to those of the pigs on the conventional SBM diet.

\section{Material and methods}

The growth trial was conducted with 160 growing pigs mainly of Yorkshire $(47.2 \%)$, F1-crossbred (Finnish landrace x Yorkshire; 14.5\%), F2crossbred (Finnish landrace or Yorkshire x F1; $22.0 \%)$ or Finnish landrace $(13.2 \%)$ origin. The pigs were divided into four similar groups of 40 animals each, based on breed, litter-origin, sex and live-weight, and were allotted at random to one of the four experimental treatments. Four pigs of the same sex were placed in each pen. Each treatment was tested with 10 replicates. The mean initial live weight of the animals was 25.5 (SE 0.28) kg.

Barley-based experimental diets contained either SBM (diet 1) or WDS (diets 2, 3 and 4) as a protein supplement (Table 1). The level of protein supplement in diets 1 and 2 was fixed to contain a similar amount of lysine $(7.6 \mathrm{~g} / \mathrm{feed}$ unit, feed unit calculated according to Tuori et al. 1995). The lysine contents were below the recommendations for growing pigs because dietary lysine mainly originated from the feed ingredients. The other WDS diets ( 3 and 4 ) were similar to diet 2 , but were fortified with synthetic L-lysine-hydrocloride (Eurolysine) to provide 9.2 and $10.7 \mathrm{~g}$ lysine/FU (2.9 and $5.1 \mathrm{~g}$ added lysine/FU), respectively. The experimental diets also contained minerals and vitamins to fulfill the requirements of growing pigs (Tuori et al. 1995). The crude protein (CP) contents of the diets 1, 2, 3 and 4 were 167, 202, 204 and 206 $\mathrm{g} / \mathrm{kg} \mathrm{DM}$, respectively.

The WDS was delivered weekly from the Alko Ltd. Koskenkorva plant during the experiment. It was the product of an integrated starchethanol process, which uses barley as a raw material (Näsi 1988). In this process, WDS was separated from wet distillers' solubles by centrifugation. It was preserved with sodium benzoate $(3 \mathrm{~g} / \mathrm{kg})$ and stored at the Swine Research Station as in the previous experiment (Valaja et al. 1995).

The pigs were housed in partially slatted pens with concrete floors. They were fed twice daily and had free access to water. Feeds were given on a restricted scale in relation to age (1.2-2.8 $\mathrm{FU} /$ day/animal); the daily allowance was increased by $0.2 \mathrm{FU} /$ week in the beginning, and by $0.1 \mathrm{FU} /$ week after the eighth experimental week. Feed consumption was recorded daily and the pigs were weighed at two week intervals. When the pigs reached $97 \mathrm{~kg}$, they were sent to an abattoir. The carcass dissection of the pigs 
Vol. 5 (1996): 157-166.

Table 1. Composition of diets containing wet distillers' solids supplemented with synthetic lysine for growing pigs and their calculated analysis.

\begin{tabular}{lrrrr}
\hline Diet & 1 & 2 & 3 & 4 \\
\hline Component, g/kg DM & & & & \\
Barley & 843 & 753 & 751 & 749 \\
Wet distillers' solids & - & 209 & 209 & 209 \\
Soyabean meal & 123 & - & - & - \\
L-lysine-HCl & - & 0.7 & 2.9 & 5.1 \\
Limestone & - & 4.2 & 3.3 & 3.3 \\
Minerals and vitamins & 34 & 33.3 & 33.3 & 33.3 \\
& & & & \\
Calculated analysis & & & & \\
Crude protein, g/kg DM & 167 & 202 & 204 & 206 \\
Digestible crude protein, g/FU & 127 & 151 & 153 & 154 \\
Lysine, g/FU & 7.6 & 7.7 & 9.2 & 10.7 \\
Lysine, g/16 g N & 5.0 & 4.3 & 5.0 & 5.8 \\
Digestible lysine, g/FU & 6.0 & 5.9 & 7.4 & 9.0 \\
Digestible lysine, g/16 g N & 3.9 & 3.3 & 4.0 & 4.9 \\
Methionine+Cystine ${ }^{\mathrm{d}}, \mathrm{g} / \mathrm{FU}$ & 4.7 & 8.7 & 8.7 & 8.7 \\
Threonine, g/FU & 5.2 & 6.3 & 6.3 & 6.3 \\
Calcium, g/FU $_{\text {Phosphorus, g/FU }}$ & 8.0 & 9.0 & 8.7 & 8.7 \\
NE', MJ/kg DM & 6.7 & 7.2 & 7.2 & 7.2 \\
Feed units $^{\mathrm{c}}, \mathrm{FU} / \mathrm{kg}$ DM & 10.2 & 10.3 & 10.3 & 10.3 \\
\hline
\end{tabular}

a Supplied per kg of diet DM: Ca 7.6 g; P 3.4 g; Mg 0.3 g; NaCl 3.5 g; Fe 153 mg; Zn 92 mg; Mn 44 mg; Cu $34 \mathrm{mg}$; Co $1.2 \mathrm{mg}$; I $0.2 \mathrm{mg}$; Se $0.14 \mathrm{mg}$; vitamin A $4860 \mathrm{IU}$; vitamin D3 $780 \mathrm{mg}$; vitamin E $24 \mathrm{mg}$; thiamin $1.9 \mathrm{mg}$; riboflavin $6.8 \mathrm{mg}$; pyridoxine $3.9 \mathrm{mg}$; pantothenic acid $14.6 \mathrm{mg}$; folic acid $3.9 \mathrm{mg}$; B12vitamin $19 \mu \mathrm{g}$; biotin $136 \mu \mathrm{g}$.

b NE calculated according to Tuori et al. (1995).

c Feed unit $=$ NE/9.3.

d the contents obtained from Valaja et al. (1995).

was performed according to Valaja et al. (1993). The WDS diets were composed of a mixture of dry ingredients (barley, synthetic lysine and minerals and vitamins) and WDS which were weighed separately and mixed just before feeding in a trough. The SBM diet was a meal-type mixture and it was mixed with water (1:2) before feeding. The allowance of WDS was adjusted weekly according to the DM content of each batch.

A standard feed analysis was conducted for barley, WDS and SBM (AOAC 1984). Ether extract was analysed after acid hydrolysis. During the experiment, the DM and CP contents of WDS were determined from every batch $(\mathrm{n}=34)$ and the whole feed analysis of WDS was determined from seven pooled samples. The analyses were performed in duplicate. The amino acids of WDS were determined from seven pooled samples by high-performance liquid chromatography after hydrolysis with $6 \mathrm{~N} \mathrm{HCl}$ at $110^{\circ} \mathrm{C}$ for $23 \mathrm{~h}$. The amino acids of barley and SBM were determined by gas chromatography after hydrolysis with 6 $\mathrm{N} \mathrm{HCl}$ at $110^{\circ} \mathrm{C}$ for $20 \mathrm{~h}$ (Näsi and Huida 1982).

The data were subjected to analysis of variance using the GLM procedure of SAS (1985). The model used to analyse the data was:

$$
\mathrm{y}_{\mathrm{ijkl}}=\mu+\mathrm{t}_{\mathrm{i}}+\mathrm{s}_{\mathrm{j}}+(\mathrm{t} * \mathrm{~s})_{\mathrm{ij}}+\mathrm{e}_{\mathrm{ijk}}
$$

where $y_{i j k l}$ is the dependent variable; $\mu$ is the 
Valaja, J. et al.: Lysine supplementation of barley wet distillers' solids diets for growing-finishing pigs

Table 2. Chemical composition of wet distillers' solids, soyabean meal and barley used in the experiment.

\begin{tabular}{lcrrrrr}
\hline & $\begin{array}{c}\text { Wet distillers' solids } \\
\text { Mean }\end{array}$ & SD & Min. & Max. & Soyabean meal & Barley \\
& 7 & & & & & \\
\hline No of observations & $192^{\mathrm{a}}$ & 16.4 & 162 & 250 & 877 & 861 \\
Dry matter, g/kg & $537^{\mathrm{a}}$ & 25.9 & 442 & 575 & 512 & 126 \\
Crude protein, g/kg DM & 65 & 3.1 & 61 & 71 & 29 & 22 \\
Ether extract, g/kg DM & 30 & 4.2 & 22 & 32 & 65 & 49 \\
Crude fibre, g/kg DM & 320 & 36.0 & 285 & 385 & 331 & 776 \\
N-free extract, g/kg DM & 62 & 5.3 & 56 & 68 & 63 & 27 \\
Ash, g/kg DM & & & & & & \\
& & & & & & \\
Amino acids, g/160 g N & 40 & 3.2 & 36 & 45 & 64 & 39 \\
Lysine & $\mathrm{ND}$ & & & & 41 & 29 \\
Threonine & $\mathrm{ND}$ & & & & 10 & 14 \\
Methionine & 19 & 1.3 & 17 & 21 & 23 & 18 \\
Histidine & 67 & 3.3 & 62 & 71 & 77 & 62 \\
Leucine & 42 & 2.1 & 38 & 44 & 51 & 35 \\
Isoleucine & 56 & 2.7 & 51 & 59 & 53 & 46 \\
Phenylalanine & 51 & 11.0 & 41 & 63 & 66 & 45 \\
Arginine & & & & & & \\
\hline
\end{tabular}

ND, Not determined.

SD, Standard deviation.

a Number of observations was 34 .

overall mean; $\mathrm{t}_{\mathrm{i}}$ is the effect of the treatment; $\mathrm{s}_{\mathrm{j}}$ is the effect of the sex; $\left(t^{*} s\right)_{i j}$ is the effect of the interaction between the treatment and sex.; $e_{i j k}$ is a normally distributed random variable. Initial weight was used as a covariate when testing the growth performance. The mean of the pen was used as an experimental unit in all the analyses. The linear and quadratic effects of lysine level were tested with orthogonal polynomials. The SBM diet was tested against each WDS diet with the Dunnett t-test .

\section{Results}

During the experiment 34 batches of WDS were used. The average DM, CP and lysine contents of WDS batches were $192 \mathrm{~g} / \mathrm{kg}, 537 \mathrm{~g} / \mathrm{kg}$ DM and $40 \mathrm{~g} / 160 \mathrm{~g} \mathrm{~N}$, respectively (Table 2) and they varied from 162 to $250 \mathrm{~g} / \mathrm{kg}, 442$ to $575 \mathrm{~g} / \mathrm{kg}$ $\mathrm{DM}$ and 36 to $45 \mathrm{~g} / 160 \mathrm{~g} \mathrm{~N}$, respectively. The variation was the highest in DM and lysine content.

One animal from treatment 4 was lost due to an intestinal obstruction and four animals were removed from the experiment because of retarded growth (two pigs from treatment 4) and tail biting (two pigs from treatment 3 ). The death and removals were not related to the experimental treatments. Two pens of the excluded pigs were also removed from the feed consumption data set because the feed consumption of the remaining pen-mates could not be precisely estimated. By mistake an uneven number of pens per sex was divided in treatment 1 (4 and 6 pens for gilts and castrated male pigs, respectively). Refusals of the diets were negligible. However, it was noticed that the pigs on WDS diets (2, 3, and 4) tended to eat their daily allowance more slowly than those on SBM diet did.

The calculated daily lysine supply was main- 
Vol. 5 (1996): 157-166.

Table 3. Performance of the pigs between weeks 1 and 5 and from the 6 th week onward on diets composed of soyabean meal or wet distillers' solids supplemented with synthetic lysine (LS-means of the treatments are presented).

\begin{tabular}{|c|c|c|c|c|c|c|c|}
\hline Treatment & 1 & 2 & 3 & 4 & SEM $^{\mathrm{b}}$ & $\begin{array}{c}\text { Effect of } \\
\text { lysine level }\end{array}$ & \\
\hline Protein suppl. & SBM & WDS & WDS & WDS & & Linear & Quadr. \\
\hline Lysine level g/FU & 7.6 & 7.7 & 9.2 & 10.7 & & & \\
\hline \multicolumn{8}{|l|}{ 1-5 weeks } \\
\hline Initial weight, $\mathrm{kg}$ & 24.6 & 24.8 & 24.8 & 24.7 & 0.28 & NS & NS \\
\hline Final weight, kg & 46.5 & $43.1^{\mathrm{a}}$ & 47.2 & 48.0 & 0.60 & $* * *$ & * \\
\hline Daily weight gain, $\mathrm{g}$ & 662 & $557^{a}$ & 681 & 708 & 17.4 & $* * *$ & $*$ \\
\hline Daily lysine intake, $g$ & 11.9 & $10.6^{a}$ & $12.7^{a}$ & $14.8^{\mathrm{a}}$ & 0.14 & $* * *$ & NS \\
\hline FCR, FU/kg gain & 2.45 & $2.84^{a}$ & 2.34 & 2.31 & 0.088 & $* * *$ & $*$ \\
\hline $\begin{array}{l}\text { FCR, NE MJ/kg gain } \\
\text { 6th week onward }\end{array}$ & 22.7 & $26.3^{a}$ & 21.7 & 21.4 & 0.81 & $* * *$ & * \\
\hline Initial weight, kg & 46.5 & $43.1^{\mathrm{a}}$ & 47.2 & 48.0 & 0.60 & $* * *$ & * \\
\hline Final weight, kg & 99.3 & 99.4 & 99.3 & 100.2 & 0.46 & NS & NS \\
\hline Experimental days & 60.4 & $68.1^{\mathrm{a}}$ & 57.2 & 56.5 & 1.79 & $* * *$ & $*$ \\
\hline Daily weight gain, $\mathrm{g}$ & 889 & 847 & 918 & 931 & 13.2 & $* * *$ & o \\
\hline Daily lysine intake, $g$ & 19.2 & $17.9^{\mathrm{a}}$ & $21.0^{\mathrm{a}}$ & $24.5^{\mathrm{a}}$ & 0.27 & $* * *$ & NS \\
\hline FCR, FU/kg gain & 2.96 & 3.03 & $2.79^{a}$ & $2.81^{\mathrm{a}}$ & 0.041 & $* * *$ & * \\
\hline $\mathrm{FCR}, \mathrm{NE} \mathrm{MJ/kg}$ gain & 27.6 & 28.1 & $25.8^{\mathrm{a}}$ & $26.0^{\mathrm{a}}$ & 0.38 & $* * *$ & $*$ \\
\hline
\end{tabular}

Significance: NS = non-significant, $o=p<0.10,^{*}=p<0.05$ and ${ }^{* * *}=p<0.001$.

SBM = soyabean meal, WDS=wet distillers' solids.

a Values differ from control treatment (1) with a 0.05 probability level.

b Standard error of the means (SEM) for treatment 1 is the table value multiplied by 1.206.

ly in accordance with the designed contents of the diets (Table 3 and 4). However, the lysine supply of the pigs on the WDS diet with the lowest lysine content was lower than that of the pigs on the SBM diet $(\mathrm{p}<0.05)$ although the diets were planned to contain similar amount of lysine.

Lysine supplementation linearly improved daily weight gain (DG) and feed conversion ratio (FCR) of the pigs both on growing (1-5 weeks) $(\mathrm{p}<0.001)$ and finishing periods (from 6 th week onwards) ( $<<0.001)$ (Table 3) although some levelling off was observed at the highest lysine supplementation level (quadratic effect in DG; $\mathrm{p}<0.05$ during growing period and $\mathrm{p}<0.10$ during finishing period). The DG and FCR of the pigs offered the WDS diet with the lowest lysine content differed from those of the pigs on the SBM diet during growing period $(p<0.05)$. During the finishing period, the DG and FCR of the pigs offered the WDS diet with the lowest lysine content and the SBM diet were similar. However, the FCR of the pigs on the SBM diet was poorer than that of the pigs on the WDS diets containing lysine 9.2 and $10.7 \mathrm{~g} / \mathrm{FU}$ $(\mathrm{p}<0.05)$.

During the experiment, both the DG and FCR of the pigs improved linearly with the lysine supplementation $(\mathrm{p}<0.001)$ (Table 4). Similar to periodical data, they also levelled off at the content of $9.2 \mathrm{~g} / \mathrm{FU}$ and daily supply of 18.0 g/day (quadratic effect: $p<0.05$ for DG and $\mathrm{p}<0.01$ for FCR). The DG and FCR of the pigs offered the SBM diet were better than those of the pigs on the WDS diet with the lysine content of $7.7 \mathrm{~g} / \mathrm{FU}(\mathrm{p}<0.05)$. However, lysine supplementation improved the DG and FCR of the pigs on the WDS diets to the level or above that of the pigs on SBM diet (lysine content of $9.2 \mathrm{~g} / \mathrm{FU}$, 
Valaja, J. et al.: Lysine supplementation of barley wet distillers' solids diets for growing-finishing pigs

Table 4. Performance and carcass quality of the pigs fed soyabean meal or wet distillers' solids diets supplemented with synthetic lysine (LS-means are presented).

\begin{tabular}{|c|c|c|c|c|c|c|c|c|c|c|c|}
\hline \multirow{3}{*}{$\begin{array}{l}\text { Treatment } \\
\text { Protein suppl. } \\
\text { Lysine level g/FU }\end{array}$} & \multirow{3}{*}{$\begin{array}{r}1 \\
\text { SBM } \\
7.6\end{array}$} & \multirow{3}{*}{$\begin{array}{r}2 \\
\text { WDS } \\
7.7\end{array}$} & \multirow{3}{*}{$\begin{array}{r}3 \\
\text { WDS } \\
9.2\end{array}$} & \multirow{3}{*}{$\begin{array}{c}4 \\
\text { WDS } \\
10.7\end{array}$} & \multirow[t]{3}{*}{$\mathrm{SEM}^{d}$} & \multicolumn{2}{|c|}{ Effect of lysine level } & \multicolumn{2}{|c|}{ Sex } & \multirow[t]{3}{*}{$\mathrm{SEM}^{c}$} & \multirow[t]{3}{*}{ Signif. } \\
\hline & & & & & & Linear & Quadrat. & Females & Castrated & & \\
\hline & & & & & & & & & males & & \\
\hline Animals & 40 & 40 & 38 & 37 & & & & 72 & 83 & & \\
\hline Initial weight, $\mathrm{kg}$ & 24.6 & 24.8 & 24.8 & 24.7 & 0.28 & NS & NS & 24.5 & 24.9 & 0.19 & NS \\
\hline Final weight, kg & 99.3 & 99.7 & 99.2 & 100.0 & 0.46 & NS & NS & 99.9 & 99.3 & 0.32 & NS \\
\hline Final weight corr., $\mathrm{kg}^{\mathrm{a}}$ & 99.5 & 99.7 & 99.9 & 100.6 & 0.53 & NS & NS & 100.5 & 99.3 & 0.37 & $*$ \\
\hline Carcass weight, $\mathrm{kg}$ & 73.7 & 73.8 & 73.9 & 74.4 & 0.39 & NS & NS & 74.4 & 73.5 & 0.27 & * \\
\hline Slaughter loss, \% & 25.8 & 26.0 & 25.5 & 25.6 & 0.28 & NS & NS & 25.5 & 26.0 & 0.19 & NS \\
\hline Experimental days & 92.8 & $101.2^{b}$ & 90.3 & 89.2 & 1.47 & $* * *$ & $*$ & 94.3 & 92.5 & 1.03 & NS \\
\hline Daily weight gain, $\mathrm{g}$ & 810 & $750^{b}$ & 838 & $855^{b}$ & 11.1 & $* * *$ & * & 812 & 814 & 7.8 & NS \\
\hline \multicolumn{12}{|l|}{ Feed consumption } \\
\hline kg DM/animal & 191.0 & 200.5 & 178.6 & 179.5 & 3.56 & $* * *$ & $*$ & 189.8 & 184.9 & 2.46 & NS \\
\hline Lysine intake, g/day & 16.6 & $15.5^{\mathrm{b}}$ & $18.0^{b}$ & $20.9^{b}$ & 0.19 & $* * *$ & NS & 17.7 & 17.8 & 0.13 & NS \\
\hline $\mathrm{FCR}, \mathrm{kg} \mathrm{DM} / \mathrm{kg}$ gain & 2.55 & 2.67 & $2.37^{\mathrm{b}}$ & $2.37^{b}$ & 0.040 & $* * *$ & ** & 2.49 & 2.49 & 0.031 & NS \\
\hline FCR, FU/kg gain & 2.80 & $2.97^{\mathrm{b}}$ & $2.63^{b}$ & $2.63^{b}$ & 0.044 & $* * *$ & $* *$ & 2.76 & 2.76 & 0.031 & NS \\
\hline FCR, NE MJ/kg gain & 26.1 & $27.6^{b}$ & $24.4^{\mathrm{b}}$ & $24.4^{\mathrm{b}}$ & 0.41 & $* * *$ & ** & 25.6 & 25.5 & 0.28 & NS \\
\hline Back fat thickness, mm & 23.6 & 22.9 & 22.6 & 23.1 & 0.58 & NS & NS & 21.9 & 24.2 & 0.40 & $* * *$ \\
\hline Side fat thickness, mm & 16.2 & 16.5 & $14.6^{\mathrm{b}}$ & 15.5 & 0.47 & NS & $*$ & 14.3 & 17.1 & 0.32 & $* * *$ \\
\hline Area of longissimus dorsi, $\mathrm{cm}^{2}$ & $1^{2} 39.1$ & 39.6 & $41.7^{\mathrm{b}}$ & $41.5^{\mathrm{b}}$ & 0.64 & o & NS & 41.7 & 39.2 & 0.44 & $* * *$ \\
\hline Lean in valuable cuts, $\%$ & 81.3 & 81.2 & 82.4 & 81.8 & 0.44 & NS & NS & 82.9 & 80.4 & 0.30 & $* * *$ \\
\hline Carcass lean, \% & 54.6 & 54.6 & 55.6 & 54.5 & 0.49 & NS & NS & 55.5 & 54.1 & 0.34 & $* *$ \\
\hline
\end{tabular}

WDS = wet distillers' solids; $\mathrm{SBM}=$ soyabean meal.

Significance: NS=non-significant, $\mathrm{o}=\mathrm{p}<0.10,{ }^{*}=\mathrm{p}<0.05,{ }^{*}=\mathrm{p}<0.01$ and $* * *=\mathrm{p}<0.001$.

${ }^{a}$ Final weight corrected by $26.0 \%$ loss at slaughter.

${ }^{\mathrm{b}}$ Values differ from treatment 1 with a 0.05 probability level.

${ }^{c}$ Standard error of the means (SEM) for females is the table value multiplied by 1.055 .

${ }^{d}$ Standard error of the means (SEM) for treatment 1 is the table value multiplied by 1.206 .

$\mathrm{p}<0.05$ in FCR and lysine content of $10.7 \mathrm{~g} / \mathrm{FU}$, $\mathrm{p}<0.05$ in DG and FCR).

Lysine supplementation, however, only had a minor effect on the carcass quality of the pigs as it only tended to increase the area of the longissimus dorsi muscle (linear effect: $\mathrm{p}<0.10$ ). The side fat thickness of the pigs on SBM diet was larger than that of the pigs on WDS diet containing lysine $9.2 \mathrm{~g} / \mathrm{FU}(\mathrm{p}<0.05)$ and the area of the longissimus dorsi muscle was smaller than that of the pigs on WDS diets containing lysine 9.2 or $10.7 \mathrm{~g} / \mathrm{FU}(\mathrm{p}<0.05)$.

The DG and FCR of the gilts and castrated male pigs were similar during the experiment and no interaction was found between sex and lysine supplementation. The gilts produced leaner carcasses than did the castrated male pigs $(\mathrm{p}<0.01)$.

\section{Discussion}

The variation in the chemical composition of WDS in the present experiment was smaller than that in the earlier growth experiments with similar feedstuffs (Valaja 1992, Valaja et al. 1995). Especially in the CP content of WDS, the standard deviation was only half of that in the study 
Vol. 5 (1996): 157-166.

of Valaja et al. (1995). However, the variation in the content of CP and lysine was still evident and caused fluctuations in the supply of protein and amino acids, which may have also influenced the performance of the pigs.

Increasing the lysine supply linearly improved the performance of the pigs in the early period of growth (1-5 weeks) although the improvement seemed to level off at the highest lysine supply level (10.7 g/FU or $14.8 \mathrm{~g} /$ day). In the study by Siljander-Rasi (1994) the performance of restrictedly fed pigs with similar genetic backgrounds improved linearly between 25 and 45 live weight up to the lysine level of $11.6 \mathrm{~g} / \mathrm{kg}$ and daily supply of $17.9 \mathrm{~g}$. The recommendations for daily lysine supply has ranged between 16.0 to $17.6 \mathrm{~g} /$ day for gilts and castrated male pigs in the experiments, where the inflection point has been reached (Yen et al. 1986a, Giles et al. 1987, Campbell et al. 1988). Also in our experiment, both sexes responded similarly to lysine supply during early period of growth.

During the finishing period the DG and FCR of the pigs levelled off at the medium lysine supply $(9.2 \mathrm{~g} / \mathrm{FU}$ and $21.0 \mathrm{~g} /$ day) because the concentrations of dietary protein and amino acids required for maximal growth decline with increasing live weight (e.g., Batterham et al. 1985, Yen et al. 1986a, 1986b, Campbell et al. 1988). Our results are in agreement with the studies of Yen et al. (1986b) and Hahn et al. (1995), in which the performance responses of gilts and castrated males to dietary lysine reached a plateau portion between 20.7 to $21.2 \mathrm{~g} /$ day and 18.6 to $23.0 \mathrm{~g} /$ day, respectively. In contrast to the other results, Campbell et al. (1988) estimated considerably lower daily lysine requirements for restrictedly fed finishing boars and gilts (16.8 and $14.1 \mathrm{~g} / \mathrm{day}$, for boars and gilts, respectively), probably because of the low genetic potential of the pigs.

Over the total experimental period response to lysine supply reached the inflection point at the dietary concentration of $9.0 \mathrm{~g} / \mathrm{FU}$ and the daily supply of $18.0 \mathrm{~g} /$ day. Similarly, SiljanderRasi (1994) reported a lysine requirement of $19 \mathrm{~g} /$ day over the total growing-finishing period.
The result is also in close agreement with the published lysine recommendations for growingfinishing pigs in Finland and Denmark (Tuori et al. 1995, Andersen and Just 1983). Many factors such as age, body weight, breed, sex, lysine availability and energy intake influence the animal responses to dietary lysine and thus make comparisons between differently designed experiments difficult.

Dietary lysine supply only had a minor effect on the carcass traits in the present study. Similar observations have been made in some of the previous experiments as well (Batterham et al. 1985, Friesen et al. 1994); although lysine response to carcass traits has usually been quite clear (e.g. Yen et al. 1986a, 1986b). However, the carcass dissection results are fairly variable (Batterham et al. 1985) and more sensitive carcass appraisal techniques may have been necessary to show the lysine response. It is also possible that the energetic efficiency of the diets increased with the lysine supply because less nitrogen was deaminated and excreted in urine and more energy was available for fat deposition. In the studies of Noblet et al. (1987) and Fuller et al. (1987) pigs on diets with high protein content exhibited a higher heat production than pigs on diets with low protein content, but similar lysine supply. In the present experiment, the protein in WDS was more efficiently used after lysine supplementation as the amino acid composition got closer to the ideal protein balance presented by Wang and Fuller 1989 (from 4.3 to 5.0 and $5.8 \mathrm{~g}$ lysine $/ 16 \mathrm{gN}$ in diets 2,3 and 4 , respectively).

The performance of the pigs on the SBM diet was clearly better than that of the pigs on the WDS diet, which was designed to contain similar amount of lysine. However, the calculated supply of lysine from the WDS diet was significantly lower, about $1 \mathrm{~g} / \mathrm{day}$, than that from the SBM diet and may have caused lower performance. The difference in the CP content between the WDS and SBM diets made comparison of the performance results difficult, as a larger part of the protein from WDS diets had to be oxidized. However, the pigs on WDS diets seemed 
Valaja, J. et al.: Lysine supplementation of barley wet distillers' solids diets for growing-finishing pigs

to need a larger lysine supply than the pigs on the SBM diet to achieve a similar growth performance.

The pigs on the WDS diets tended to eat their daily allowance more slowly than the pigs on SBM diet, which may have also influenced the results, although diet refusals or feed waste was not recorded. Valaja et al. (1995) also observed also some palatability differences between WDS and SBM diets and Suomi (1980) stated that the distilling process itself might reduce palatability of distillers feeds.

Similar to our experiment, Valaja et al. (1995) observed that the performance of the growingfinishing pigs decreased linearly when SBM was replaced by WDS as the protein supplement. The recommended use of conventional distillers' feeds has been limited to $5-10 \%$ of diets in the earlier experiments (Alaviuhkola 1978, Suomi 1980, Newman and Gras 1983), but in some reports distillers dried grains with solubles have been successfully added up to $20 \%$ of the diet (Cromwell and Stahly 1986, Cromwell and Monegue 1994). However, the high fibre content and decreased availability of protein, due to the severe drying process, are mainly responsible for the variable results with conventional distillers feeds (Näsi 1984, Cromwell et al. 1993).

There are some contradictions between the results of the performance experiments (Valaja et al. 1995 and present study) and those of the digestibility and protein utilisation studies (Näsi and Aimonen 1992, Valaja and Näsi 1996, Buraczewska et al. 1995) since the digstibility and protein utilisation of WDS have been very high. So it is quite unlikely that low protein digestibility or utilisation of WDS could have caused the results of the present experiment. Valaja et al. (1995) suggested that the variability in the chemical composition of WDS was the main reason for decreased performance. Our results support the same explanation, as considerable variation was found in the content of crude protein and lysine in WDS during the experiment.

It is concluded that lysine supplementation of WDS diets linearly improved the performance of the pigs up to the level of $9.2 \mathrm{~g} / \mathrm{FU}$ and daily supply of $18 \mathrm{~g}$ over the total growth period. The results also indicated that a higher content of lysine was needed in WDS diets than in SBM diet, mainly to balance the variation in the chemical composition of WDS during the long term experiment.

\section{References}

Alaviuhkola, T. 1978. Rankkijauho lihasikojen rehuna. Koetoiminta ja käytäntö 31.10.1978: 39.

Andersen, P.E. \& Just, A. 1983. Tabeller over foderstoffers sammensættning m.m. Kvæg Svin. S.L. Mollers Bogtryk. København. 102 p.

AOAC 1984. Official methods of analysis. 14th edition. Association of Official Analytical Chemist. Arlington, Virginia. $1141 \mathrm{p}$.

Batterham, E.S., Giles, L.R. \& Dettmann, E.B. 1985. Amino acid and energy interactions in growing pigs. 1. Effects of food intake, sex and live weight on the responses of growing pigs to lysine concentration. Animal Production 40: 331-343.

Buraczewska, L., Valaja, J., Buraczewski, S., Näsi, M. \& Gdala, J. 1996. Digestibility and availability of protein and phosphorus in pigs fed wet barley protein and wet distillers' solids from integrated starch-ethanol production. Animal Feed Science and Technology (in press).
Campbell, R.G., Taverner, M.R. \& Curic, D.M. 1988. The effects of sex and live weight on the growing pig's response to dietary protein. Animal Production 46: 123130.

Cromwell, G.L., Herkelman, K.L. \& Stahly, T.S. 1993. Physical, chemical, and nutritional characteristics of distillers dried grains with solubles for chicks and pigs. Journal of Animal Science 71: 679-686.

- \& Monegue, H.J. 1994. Utilization of corn by-products by finishing pigs. Journal of Animal Science 72: suppl. 2: 58. (Abstract)

- \& Stahly, T.S. 1986. Distillers dried grains with solubles for growing-finishing swine. Proceedings of 41 st Distillers Feed Conference, Cincinnati, Ohio. p. 77-88. Fuller, M.F., Cadenhead, A., Mollison, D.G. \& Seve, B. 1987. Effect of the amount and quality of dietary protein on nitrogen metabolism and heat production in growing pigs. British Journal of Nutrition 58: 277-285. 


\title{
AGRICULTURAL AND FOOD SCIENCE IN FINLAND
}

Vol. 5 (1996): 157-166.

Friesen, K.G., Nelssen, J.L., Unruh, J.A., Goodband, R.D. \& Tokach, M.D. 1994. Effect of the interrelationship between genotype, sex and dietary lysine on growth performance and carcass composition in finishing pigs fed to either 104 or 127 kilograms. Journal of Animal Science 72: 946-954.

Giles, L.R., Batterham, E.S., Dettmann, E.B. and Lowe, R.F. 1987. Amino acid and energy interactions in growing pigs. 3. Effects of sex and live weight and cereal on the responses to dietary lysine concentration when fed ad libitum or to a restricted food scale on diets based on wheat or barley. Animal Production 45: 493-502.

Hahn, J.D., BiehI, R.R. \& Baker, D.H. 1995. Ideal digestible lysine level for early- and late- finishing swine. Journal of Animal Science 73: 773-784.

Newman, C.W. \& Gras, P.W. 1983. Utilization of barley distillers dried grains in swine growing diets. Proceedings, Western Section American Society of Animal Science 34: 138-141.

Noblet, J., Henry, Y. \& Dubois, S. 1987. Effect of protein and lysine levels in the diet on body gain composition and energy utilization in growing pigs. Journal of Animal Science 65: 717-726.

Näsi, M. 1984. Evaluation of barley distillers dried grains with soluble, and condensed distillers solubles in the diet of growing pigs. Journal of Agricultural Science in Finland 56: 221-226.

- 1988. Evaluating barley feed fractions from integrated ethanol-starch production in the diets of ruminants. Journal of Agricultural Science in Finland 60: 701-709.

- \& Aimonen, E. 1992. Evaluation of undehydrated barley feed fractions and dried oat feed fractions from integrated starch-ethanol process in diets of growing pigs. Agricultural Science in Finland 1: 291-301.

- \& Huida, L. 1982. Digestibility of amino acids in pig diets containing Eurolysine bacterial protein or Pekilo protein, with special reference to a gas gromatographic method used in amino acid determination. Journal of Agricultural Science in Finland 54: 279-285.

SAS 1985. SAS User's Guide: Statistics. 5 th Ed. SAS
Institute Inc, Cary, NC, USA. 956 p.

Siljander-Rasi, H. 1994. Lihasikojen vaiheruokinta. Sika 24: 8-10.

Suomi, K. 1980. Tuore rankki lihasikojen rehuna. Koetoiminta ja käytäntő 1.7.1980: 28.

Susenbeth, A. 1995. Factors affecting lysine utilization in growing pigs: an analysis of literature data. Livestock Production Science 43: 193-204

Tuori, M., Kaustell, K., Valaja, J., Aimonen, E., Saarisalo, E. \& Huhtanen, P. 1995. Rehutaulukot ja ruokintasuositukset. Mărehtijăt - siat - siipikarja - turkiselăimet hevoset. Yliopistopaino, Helsinki. ISBN 951-46-6971-7. $99 \mathrm{p}$.

Valaja, J. 1992. The effect of supplementation of liquid and crystalline lysine to barley- distillers solids diet on the performance and carcass quality of pigs. Agricultural Science in Finland 1: 559-567.

-, Alaviuhkola, T. \& Siljander-Rasi, H. 1995. Wet barley distillers solids as a protein source for growing pigs. Animal Feed Science and Technology 51: 193-202.

-, Alaviuhkola, T. \& Suomi, K. 1993. Reducing crude protein content with supplementation of synthetic lysine and threonine in barley-rapeseed meal-pea diets for growing pigs. Agricultural Science in Finland 2: 117-123.

- \& Näsi, M. 1996. Digestibility and utilisation of diets composed of wet distillers' solids or soyabean meal and supplemented with liquid lysine product for growing pigs. Animal Feed Science and Technology 57: 267-279.

Wang, T.C. \& Fuller, M.F. 1989. The optimum dietary amino acid pattern for growing pigs. 1. Experiments by amino acid deletion. British Journal of Nutrition 62: 7789.

Yen, H.T., Cole, D.J.A. \& Lewis, D. 1986a. Amino acid requirements of growing pigs. 7.The response of pigs from 25 to $55 \mathrm{~kg}$ live weight to dietary ideal protein. Animal Production 43: 141-154.

-, Cole, D.J.A. \& Lewis, D. 1986b. Amino acid requirements of growing pigs. 8 . The response of pigs from 50 to $90 \mathrm{~kg}$ live weight to dietary ideal protein. Animal Production 43: 155-165.

\section{SELOSTUS}

\section{Rankkivalkuaisdieetin lysiinitäydennyksen vaikutus sikojen tuotantotuloksiin}

\author{
Jarmo Valaja, Hilkka Siljander-Rasi, Timo Alaviuhkola ja Asko Rantanen \\ Maatalouden tutkimuskeskus ja Primalco Oy
}

Kasvatuskokeessa tutkittiin rankkivalkuaisdieetin erilaisten lysiinitäydennysten vaikutusta sikojen tuotantotuloksiin ja teuraslaatuun. Kokeessa oli mukana 160 sikaa, jotka jaettiin neljään yhtä suureen ryhmään ja kasvatettiin sukupuolet erillään neljän sian karsinois- sa $25,5 \mathrm{~kg}$ alkupainosta $100 \mathrm{~kg}$ loppupainoon. Kolmea samanlaista ohra-rankkivalkuaisdieettiä täydennettiin eri määrillä puhdasta lysiiniä, ja kontrolliruokintana oli ohra-soijarouhedieetti. Soijarouhepohjainen dieetti sisälsi raakavalkuaista $167 \mathrm{~g} / \mathrm{kg}$ kuiva-ai- 


\section{AGRICULTURAL AND FOOD SCIENCE IN FINLAND}

Valaja, J. et al.: Lysine supplementation of barley wet distillers' solids diets for growing-finishing pigs

netta (KA) ja lysiiniä 7,6 g/rehuyksikkö (ry). Rankkivalkuaispohjaisten dieettien raakavalkuaispitoisuus oli $204 \mathrm{~g} / \mathrm{kg} \mathrm{KA}$ ja lysiinipitoisuudet 7,7 g/ry, 9,2 g/ry ja $10,7 \mathrm{~g} /$ ry lysiinitäydennyksen jälkeen. Nestemäinen rankkivalkuainen oli valmistettu ohrasta Primalco Oy:n Koskenkorvan tehtailla.

Sikojen päiväkasvu ja rehun hyväksikäyttö paranivat suoraviivaisesti rankkivalkuaispohjaisen dieetin lysiinipitoisuuden kasvun myötä. Lysiinin tuotantotuloksia parantava vaikutus oli selvin kasvukauden alkuvaiheessa (1-5 viikkoa). Loppukasvatuksessa dieetin suurin lysiinitaso $(10,7 \mathrm{~g} / \mathrm{ry})$ ei enää paranta- nut sikojen tuotantotuloksia. Koko kasvukauden aikana dieetin optimaalinen lysiinitaso oli 9,2 g/ry. Lysiinitäydennyksen vaikutukset sikojen teuraslaatuparametreihin olivat pieniä. Soijarouhedieettiä syöneiden sikojen kasvu ja rehuhyötysuhde olivat paremmat kuin saman lysiinimäärän sisältävää rankkivalkuaisdieettiä saaneiden sikojen.

Lysiinitäydennyksellä voidaan merkittävästi tehostaa niukasti lysiiniä sisältävän rankkivalkuaisen hyväksikäyttöä. Lihasikojen ruokinnassa rankkivalkuaispohjaisen dieetin lysiiniannostuksen on oltava suurempi kuin käytettäessä soijapohjaista rehuseosta. 